\title{
PENGARUH IKLIM ORGANISASI, DISIPLIN KERJA DAN KEPEMIMPINAN TERHADAP KEPUASAN KERJA PEGAWAI DISNAKER DAN ESDM BALI
}

\author{
Ni Kadek Novi Saridewi ${ }^{1}$ \\ I Gusti Ayu Dewi Adnyani ${ }^{2}$ \\ ${ }^{1,2}$ Fakultas Ekonomi dan Bisnis Universitas Udayana (Unud), Bali, Indonesia \\ e-mail: novisaridewi242@yahoo.com
}

\begin{abstract}
ABSTRAK
Tujuan penelitian ini adalah untuk menganalisis pengaruh iklim organisasi, disiplin kerja, dan kepemimpinan terhadap kepuasan kerja pegawai Dinas Tenaga Kerja dan Energi Sumber Daya Mineral Provinsi Bali. Populasi penelitian ini adalah seluruh pegawai tetap Dinas Tenaga Kerja dan Energi Sumber Daya Mineral Provinsi Bali. Pengambilan sampel menggunakan teknik sampel jenuh, dimana seluruh populasi penelitian dipilih menjadi sampel. Jumlah pegawai tetap Dinas Tenaga Kerja dan Energi Sumber Daya Mineral Provinsi Bali sebanyak 75 orang, sehingga jumlah sampel yang digunakan adalah sebanyak 75 orang. Data yang dikumpulkan dianalisis dengan regresi linear berganda. Hasil analisis menunjukkan Iklim organisasi, disiplin kerja, dan kepemimpinan berpengaruh positif dan signifikan terhadap Kepuasan kerja pegawai Dinas Tenaga Kerja dan Energi Sumber Daya Mineral Provinsi Bali. Semakin baik iklim organisasi, semakin tinggi sikap disiplin pegawai dan semakin baik kepemimpinan di Dinas Tenaga Kerja dan Energi Sumber Daya Mineral Provinsi Bali maka akan semakin meningkatkan kepuasan kerja yang dirasakan pegawai.
\end{abstract}

Kata Kunci: iklim organisasi, disiplin kerja, kepemimpinan, kepuasan kerja

\begin{abstract}
The purpose of this study is to analyze the influence of organizational climate, work discipline, and leadership on job satisfaction of the employees of the Office of Manpower and Energy of Mineral Resources of Bali Province. The population is all permanent employees of the Office of Manpower and Energy Mineral Resources of Bali Province. Sampling is using census sample technique, in which the entire study population will be selected to be sampled. The total number of permanent employees of the Department of Manpower and Energy of Mineral Resources of Bali Province is 75 people number of samples is 75 people. The data collected in this study were analyzed using multiple linear regression. The result of the analysis shows that organization climate, work discipline, and leadership have positive and significant influence to the job satisfaction of the employee of the Department of Manpower and Energy of Mineral Resources of Bali Province.
\end{abstract}

Keywords: organizational climate, work discipline, leadership, job satisfaction 


\section{PENDAHULUAN}

Modal dasar dalam pembangunan nasional salah satunya adalah Sumber Daya Manusia (SDM) yang berkualitas, maka dari itu diperlukan pengembangan dan arahan yang jelas terhadap kualitas SDM agar bisa mencapai tujuan yang diharapkan. Saat menjalankan sistem dan manajemen pemerintahan yang baik tentu diperlukan Sumber Daya Aparatur (SDA) yang handal dan terampil agar siklus sistem manajemen kepemerintahan bisa berjalan dengan efektif dan efisien dalam mencapai suatu tujuan yaitu mensejahterakan masyarakat. Salah satu kunci penting dari berjalannya sistem dan manajemen pemerintahan yang baik adalah kedisiplinan (Atmaja dkk., 2016).

Pegawai negeri sipil sebagai salah satu Sumber Daya Aparatur (SDA) Pemerintah memiliki kewajiban untuk memberikan pelayanan yang baik kepada masyarakat. Untuk mencapai kinerja yang baik, tentunya pegawai negeri harus memiliki kedisiplinan. Pegawai yang sudah memiliki kedisiplinan kerja yang baik akan dengan mudah menjalankan setiap pekerjaan dan tanggungjawab yang diberikan, tidak hanya dalam lingkup pekerjaan tetapi dalam kehidupan sehariharinya akan sangat mudah membagi waktu dan menjalankan aktivitasnya dengan baik. Namun, pada kenyataannya belum semua pegawai negeri mampu menerapkan kedisiplinan dengan baik. Pernyataan tersebut didukung dengan data yang di publikasi oleh beberapa media terkait pelanggaran disiplin yang dilakukan oleh lima anggota PNS di Denpasar. Media Tribun Bali pada bulan Februari 2017 lalu melaporkan bahwa terdapat lima Pegawai Negeri Sipil (PNS) di Denpasar yang diberhentikan lantaran sering tidak masuk kerja tanpa keterangan. Hal 
tersebut menunjukkan bahwa masih ada pegawai negeri sipil di Pemerintah Kota Denpasar yang kurang disiplin dalam bekerja.

Seorang Pegawai Negeri Sipil yang melayani masyarakat, harus menerapkan disiplin demi kepuasan masyarakat. Sebab masyarakat merupakan objek dari pelayan itu sendiri. Aparatur Sipil Negera (ASN) diharapkan dapat menumbuhkan budaya kerja dengan etos kerja yang baik dan disiplin tinggi sehingga tujuan penyelenggaraan pemerintahan dapat terwujud. Para pegawai harus disiplin dalam menjalankan tugas sebagai aparat pemerintah dan pelayan masyarakat (NusaBali, 2017).

Disiplin kerja pada pegawai negeri sipil sangat dibutuhkan, karena apa yang menjadi tujuan organisasi akan sukar dicapai jika tidak adanya disiplin kerja. Disiplin yang terbentuk dalam diri pekerja merupakan cerminan tanggungjawab seseorang dalam menjalankan tugas dan pekerjaannya sehingga dapat mendorong semangat kerja dan kepuasan kerja dalam pencapaian tujuan organisasi (Yunus dan Bachri, 2013). Bila para pegawai/pegawai memiliki disiplin kerja yang tinggi, diharapkan akan mampu menyelesaikan tugas dengan cepat dan tepat sehingga timbul kepuasan kerja (Mardiono dan Supriyatin, 2014). Kepuasan kerja pegawai harus diciptakan sebaik-baiknya supaya moral kerja, dedikasi, kecintaan, dan kedisiplinan pegawai meningkat. Oleh karena itu kepuasan kerja pegawai sangat penting dan merupakan kunci pendorong moral, kedisiplinan, prestasi kerja pegawai dalam mendukung terwujudnya tujuan perusahaan (Susanty, 2012).

Iklim organisasi juga merupakan faktor penting yang menentukan kelangsungan hidup suatu organisasi. Menurut Baron dan Byme 1994 dalam 
Chaidar (2016) ada dua kelompok faktor yang mempengaruhi kepuasan kerja. Faktor pertama yaitu organisasi yang berisi kebijaksanaan perusahaan dan iklim kerja. Faktor kedua yaitu, faktor individual atau karakteristik pegawai. Iklim organisasi yang kondusif perlu diciptakan, dengan begitu pegawai akan termotivasi untuk bertindak semaksimal mungkin demi tercapainya target-target kerja instansi. Pencapaian akan hasil pekerjaan yang positif akan memberikan kepuasan dalam diri pegawai (Akbar dkk., 2017). Iklim organisasi yang kondusif memberikan rasa aman dan memungkinkan para pegawai untuk dapat berkerja optimal. Dibutuhkan iklim organisasi yang kondusif untuk menunjang pelaksanaan tugas pegawai. Iklim organisasi merupakan faktor yang penting dalam usaha peningkatan kinerja pegawai di perusahaan (Lineker dkk., 2016). Sebuah pemahaman yang jelas tentang iklim organisasi adalah penting karena memberikan manajemen puncak dengan pemahaman tentang bagaimana meningkatkan fungsionalitas dari sebuah organisasi (McKim et al., 2011).

Iklim kerja memiliki pengaruh yang positif dan signifikan terhadap kepuasan kerja, dapat diartikan bahwa semakin baik iklim kerja yang dirasakan oleh pegawai, maka akan semakin tinggi kepuasan kerja yang dirasakan pegawai tersebut (Chaidar, 2016). Dengan demikian, iklim organisasi merupakan faktor yang cukup penting dan harus diperhitungkan dalam upaya meningkatkan kepuasan kerja (Robirodia dan Prihatin, 2016). Kepuasan kerja pegawai tidak hanya dipengaruhi oleh disiplin kerja dan disiplin kerja pegawai. Peningkatan kepuasan kerja pegawai dalam suatu organisasi juga tidak lepas dari peranan pemimpin dalam organisasi tersebut. Kepemimpinan merupakan kunci utama dan 
strategis dalam kelangsungan hidup suatu organisasi/perusahaan agar pencapain tujuan dapat tercapai secara efektif dan efisien (Yunus dan Bachri, 2013).

Kepuasan kerja meningkat apabila efektifitas kepemimpinan meningkat begitu pula sebaliknya hal ini menunjukkan efektifitas kepemimpinan mempunyai pengaruh terhadap kepuasan kerja, maka dari itu pimpinan dalam suatu organisasi perusahaan dituntut untuk mampu menciptakan kondisi yang mampu memuaskan pegawai dalam bekerja dengan memenuhi kebutuhan-kebutuhan individu dan kebutuhan organisasi secara manusiawi (Robbins 2001:18). Seseorang dengan kepuasan kerja yang tinggi akan menunjukan sikap positif terhadap pekerjaan itu, sedangkan yang tidak puas dengan pekerjaannya menunjukan sikap negatif. Misalnya jika seorang pegawai merasa bahwa dia telah bekerja lebih keras dibandingkan yang lain tetapi mereka merasa kurang dihargai, maka kemungkinan besar dia akan memiliki sikap negatif terhadap pekerjaannya, atasannya dan rekan kerjanya, dia akan merasa tidak puas. Sebaliknya jika dia merasa mendapat perlakuan yang baik dan mendapat upah yang sesuai, dia akan bersifat positif terhadap pekerjaannya dan merasa puas dengan pekerjaannya (Satriyo dan Idris, 2015). Styawahyuni dan Yuniari (2014) mengungkapkan bahwa pegawai yang memiliki tingkat kepuasan kerja yang cukup dalam perusahaan memiliki peran penting dalam pencapaian tujuan perusahaan.

Upaya meraih kepuasan kerja pegawai dan meraih tujuan organisasi harus di upayakan bagaimana cara seorang pemimpin dapat memberikan dorongan semangat kerja kepada pegawai, agar sasaran maupun tujuan yang di rencanakan secara bersama dapat mencapai target. Selain itu, pemimpin dapat memberikan 
promosi jabatan bagi pegawai yang berprestasi agar, terciptanya kepuasan kerja pegawai (Simanungkalit, 2013). Pemimpin juga perlu melakukan pembinaan yang sungguh-sungguh terhadap pegawai agar dapat menimbulkan kepuasan dan komitmen organisasi sehingga pada akhirnya dapat meningkatkan kinerja yang tinggi. Organisasi yang berhasil dalam mencapai tujuan serta mampu memenuhi tanggung jawab sosialnya akan sangat tergantung pada para pemimpin dimana apabila pemimpin mampu melaksanakan tugas dengan baik, sangat mungkin organisasi tersebut akan mencapai sasarannya (Priyono, 2012).

Pimpinan harus cukup jeli dalam memilih gaya kepemimpinan. Pada situasi dan obyek tertentu, gaya kepemimpinan bisa saja akan berubah. Pimpinan dapat menggunakan salah satu atau kombinasi dari empat gaya kepemimpinan untuk mempengaruhi persepsi para pegawai dan mampu memberikan motivasi kepada pegawai tentang kejelasan-kejelasan tugasnya, mencapai tujuan, komitmen pegawai dari pelaksanaan efektif (Waliningsuci dkk., 2017). Chaidar (2016) dalam penelitianya memperoleh hasil bahwa kepemimpinan transformasional berpengaruh positif dan signifikan terhadap kepuasan kerja. Dapat disimpulkan bahwa kepemimpinan transformasional yang baik akan meningkatkan kepuasan kerja pegawai.

Penelitian ini dilakukan di Dinas Tenaga Kerja dan Energi Sumber Daya Mineral Provinsi Bali. Alasan peneliti melakukan penelitian di Dinas Tenaga Kerja dan Energi Sumber Daya Mineral Provinsi Bali yaitu karena dinas tersebut baru saja mengalami pergantian pemimpin, sehingga perlu dilakukan evaluasi terhadap cara kepemimpinan sebelumnya agar dapat dipertimbangkan bagi 
pimpinan baru dalam membentuk iklim organisasi, meningkatkan tingkat disiplin dan menerapkan gaya kepemimpinan yang sesuai sehingga dapat meningkatkan kepuasan kerja pegawai Dinas Tenaga Kerja dan Energi Sumber Daya Mineral Provinsi Bali menjadi lebih baik dari yang sebelumnya.

Berdasarkan latar belakang tersebut, maka perlu diketahui bagaimana pengaruh iklim organisasi, disiplin kerja dan kepemimpinan terhadap kepuasan kerja pegawai Dinas Tenaga Kerja dan Energi Sumber Daya Mineral Provinsi Bali. Hasil penelitian ini diharapkan dapat dimanfaatkan oleh Dinas Tenaga Kerja dan ESDM Provinsi Bali untuk lebih meningkatkan kinerja pegawainya dengan melakukan peningkatan atau perbaikan pada indikator yang memberikan pengaruh terbesar, sehingga kinerja pegawai akan selalu mengalami peningkatan. Berdasarkan latar belakang yang telah disampaikan maka yang menjadi tujuan penelitian ini yaitu untuk mengetahui pengaruh iklim organisasi, disiplin kerja dan kepemimpinan terhadap kepuasan kerja pegawai Dinas Tenaga Kerja dan Energi Sumber Daya Mineral Provinsi Bali.

Pegawai yang memiliki tingkat kepuasan kerja yang cukup dalam perusahaan memiliki peran penting dalam pencapaian tujuan perusahaan. Dalam upaya meraih kepuasan kerja pegawai dan meraih tujuan organisasi diperlukan adanya iklim organisasi yang kondusif, disiplin kerja pegawai dan pemimpin yang dapat memberikan dorongan semangat kerja kepada pegawai, agar sasaran maupun tujuan yang di rencanakan secara bersama dapat mencapai target. Iklim organisasi yang kondusif perlu diciptakan, dengan begitu pegawai akan termotivasi untuk bertindak semaksimal mungkin demi tercapainya target-target 
kerja instansi. Pencapaian akan hasil pekerjaan yang positif akan memberikan kepuasan dalam diri pegawai (Akbar dkk., 2017). Penelitian yang dilakukan oleh Rachman (2013), (Putra dkk., 2014), Susanty (2012), Koti Akula dan Talluri (2013), Rahmawati dan Supartha (2015), Robirodia dan Prihatin (2016), serta Sutaji (2013) memperoleh hasil bahwa iklim organisasi memiliki pengaruh yang positif dan signifikan terhadap kepuasan kerja pegawai.

Kepuasan kerja dapat tercapai apabila pegawai memiliki tingkat kedisiplinan yang tinggi. Disiplin yang terbentuk dalam diri pekerja merupakan cerminan tanggungjawab seseorang dalam menjalankan tugas dan pekerjaannya sehingga dapat mendorong semangat kerja dan kepuasan kerja dalam pencapaian tujuan organisasi (Yunus dan Bachri, 2013). Bila para pegawai/pegawai memiliki disiplin kerja yang tinggi, diharapkan akan mampu menyelesaikan tugas dengan cepat dan tepat sehingga timbul kepuasan kerja (Mardiono dan Supriyatin, 2014). Penelitian yang dilakukan oleh Riyanto (2016), Mardiono dan Supriyatin (2014), Yunus dan Bachri (2013), serta Huda (2017) memperoleh hasil bahwa disiplin kerja berpengaruh positif dan signifikan terhadap kepuasan kerja pegawai, yakni semakin tinggi disiplin kerja maka semakin tinggi kepuasan kerja pegawai tersebut.

Kepuasan kerja meningkat apabila efektifitas kepemimpinan meningkat begitu pula sebaliknya hal ini menunjukkan efektifitas kepemimpinan mempunyai pengaruh terhadap kepuasan kerja, maka dari itu pimpinan dalam suatu organisasi perusahaan dituntut untuk mampu menciptakan kondisi yang mampu memuaskan pegawai dalam bekerja dengan memenuhi kebutuhan-kebutuhan individu dan 
kebutuhan organisasi secara manusiawi (Robbins 2001:18). Penelitian yang dilakukan oleh Yunus dan Bachri (2013), Wusyang dan Tawas (2016), Sapila (2013), Simanungkalit (2013), Priyono (2012) memperoleh hasil bahwa ada pengaruh yang positif dan signifikan antara gaya kepemimpinan terhadap kepuasan kerja pegawai.

Penjabaran hubungan antar variabel yang telah dipaparkan, maka konsep keterkaitan antar variabel yang akan diteliti dapat dijelaskan melalui model konseptual atau kerangka pemikiran seperti dalam Gambar 1 sebagai berikut:

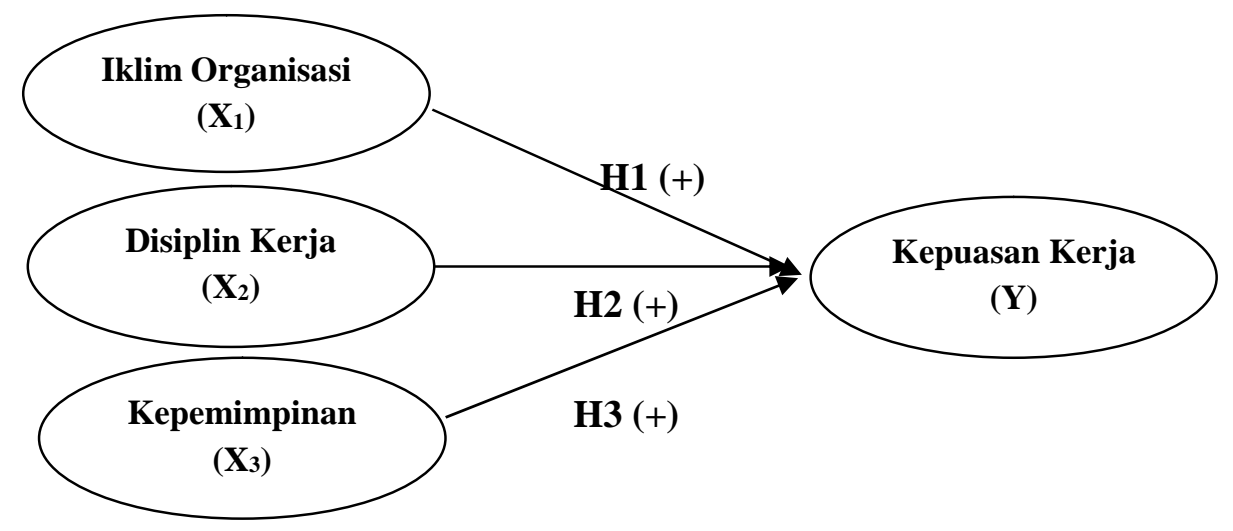

\section{Gambar 1. Kerangka Konseptual Penelitian}

Sumber: Hasil pemikiran peneliti, 2018

Berdasarkan kerangka konsep yang ada maka hipotesis disusun, sebagai berikut.

$\mathrm{H}_{1}$ : Iklim organisasi memiliki pengaruh positif dan signifikan terhadap kepuasan kerja.

$\mathrm{H}_{2}$ : Disiplin kerja memiliki pengaruh positif dan signifikan terhadap kepuasan kerja.

$\mathrm{H}_{3}$ : Kepemimpinan memiliki pengaruh positif dan signifikan terhadap kepuasan kerja. 


\section{METODE PENELITIAN}

Pendekatan yang digunakan oleh peneliti dalam penelitian ini termasuk dalam pendekatan kuantitatif yang berbentuk asosiatif. Penelitian asosiatif merupakan penelitian yang dilakukan untuk mencari hubungan antara dua variabel atau lebih dan memiliki hubungan kausal yaitu hubungan yang sifatnya sebabakibat dimana salah satu variabel yang mempengaruhi variabel lainnya. Lokasi penelitian ini dilakukan Dinas Tenaga Kerja dan Energi Sumber Daya Mineral Provinsi Bali yang beralamat di Renon, Kota Denpasar. Alasan peneliti melakukan penelitian di Dinas Tenaga Kerja dan Energi Sumber Daya Mineral Provinsi Bali yaitu karena dinas tersebut baru saja mengalami pergantian pemimpin yang tentunya dapat mempengaruhi kepuasan kerja pegawai Dinas Tenaga Kerja dan Energi Sumber Daya Mineral Provinsi Bali dengan adanya pimpinan baru tersebut

Tabel 1.

Identifikasi Variabel

\begin{tabular}{|c|c|c|}
\hline VARIABEL & INDIKATOR & REFERENSI \\
\hline $\begin{array}{l}\text { Kepuasan kerja } \\
\text { (Y) }\end{array}$ & $\begin{array}{l}\text { 1. Pembayaran (Pay), } \\
\text { 2. Pekerjaan (Job), } \\
\text { 3. Kesempatan promosi (Promotion opportunities), } \\
\text { 4. Atasan (Supervisor), } \\
\text { 5. Rekan kerja (Co-workers), }\end{array}$ & $\begin{array}{c}\text { Azzem dan } \\
\text { Shaima (2010) }\end{array}$ \\
\hline $\begin{array}{l}\text { Iklim Organisasi } \\
\qquad\left(\mathrm{X}_{1}\right)\end{array}$ & $\begin{array}{l}\text { 1. Kepemimpinan } \\
\text { 2. Kepercayaan } \\
\text { 3. Pembuatan keputusan bersama atau dukungan } \\
\text { 4. Kejujuran } \\
\text { 5. Komunikasi } \\
\text { 6. Fleksibel } \\
\text { 7. Resiko pekerjaa }\end{array}$ & Intifada (2013) \\
\hline $\begin{array}{l}\text { Disiplin kerja } \\
\qquad\left(\mathrm{X}_{2}\right)\end{array}$ & $\begin{array}{l}\text { 1. Ketepatan waktu } \\
\text { 2. Menggunakan peralatan kantor dengan baik } \\
\text { 3. Tanggung jawab yang tinggi } \\
\text { 4. Ketaatan terhadap aturan kantor }\end{array}$ & $\begin{array}{l}\text { Wulandari } \\
\text { (2017) }\end{array}$ \\
\hline $\begin{array}{l}\text { Kepemimpinan } \\
\left(\mathrm{X}_{3}\right)\end{array}$ & $\begin{array}{l}\text { 1. Inspirational Motivation } \\
\text { 2. Intelectual Stimulation } \\
\text { 3. Idealized Influence } \\
\text { 4. Individual Consideration }\end{array}$ & $\begin{array}{l}\text { Omar and Hussin } \\
\text { (2013), Munir, et } \\
\text { al,. (2012), Sun, } \\
\text { et al., (2011) }\end{array}$ \\
\hline
\end{tabular}

Sumber : Kajian peneltian sebelumnya, 2018 
Populasi dalam penelitian ini adalah seluruh pegawai tetap Dinas Tenaga Kerja dan Energi Sumber Daya Mineral Provinsi Bali. Metode penentuan sampel yang digunakan dalam penelitian ini adalah metode sampel jenuh. Sampling jenuh adalah teknik penentuan sampel bila semua anggota populasi digunakan sebagai sampel. Jumlah pegawai Dinas Tenaga Kerja dan Energi Sumber Daya Mineral Provinsi Bali sebanyak 75 orang, sehingga jumlah responden penelitian yang digunakan dalam penelitian ini adalah sebanyak 75 orang.

Data yang dikumpulkan pada penelitian ini akan dianalisis dengan menggunakan regresi linear berganda. Analisis ini dipakai untuk mengetahui ketergantungan suatu variabel terikat dengan satu atau lebih variabel bebas dalam analisis ini dibantu dengan program computer statistic pacage of social science (SPSS). Bentuk umum persamaan linear berganda adalah sebagai berikut:

$$
\mathrm{Y}=\mathrm{a}+\beta_{1} \mathrm{X}_{1}+\beta_{2} \mathrm{X}_{2}+\beta_{3} \mathrm{X}_{3}+\mathrm{e}
$$

Keterangan :

$$
\begin{array}{ll}
\mathrm{Y} & =\text { Kepuasan Kerja } \\
\mathrm{X}_{1} & =\text { Iklim Organisasi } \\
\mathrm{X}_{2} & =\text { Disiplin Kerja } \\
\mathrm{X}_{3} & =\text { Kepemimpinan } \\
\beta_{1}, \beta_{2,}, \beta_{3} & =\text { Koefisien masing-masing faktor } \\
\mathrm{e} & =\text { Kesalahan atau standard error }
\end{array}
$$

\section{HASIL DAN PEMBAHASAN}

Data penelitian diperoleh dari hasil kuesioner yang telah disebarkan kepada responden penelitian sejumlah 75 orang pegawai tetap yang bekerja di Dinas Tenaga Kerja dan Sumber Daya Mineral Provinsi Bali. Karakteristik responden 
meliputi jenis kelamin, usia, dan tingkat pendidikan responden. Ringkasan mengenai karakteristik responden dapat dilihat pada Tabel 2.

Tabel 2.

Karakteristik Pegawai Dinas Tenaga Kerja dan Sumber Daya Mineral Provinsi Bali

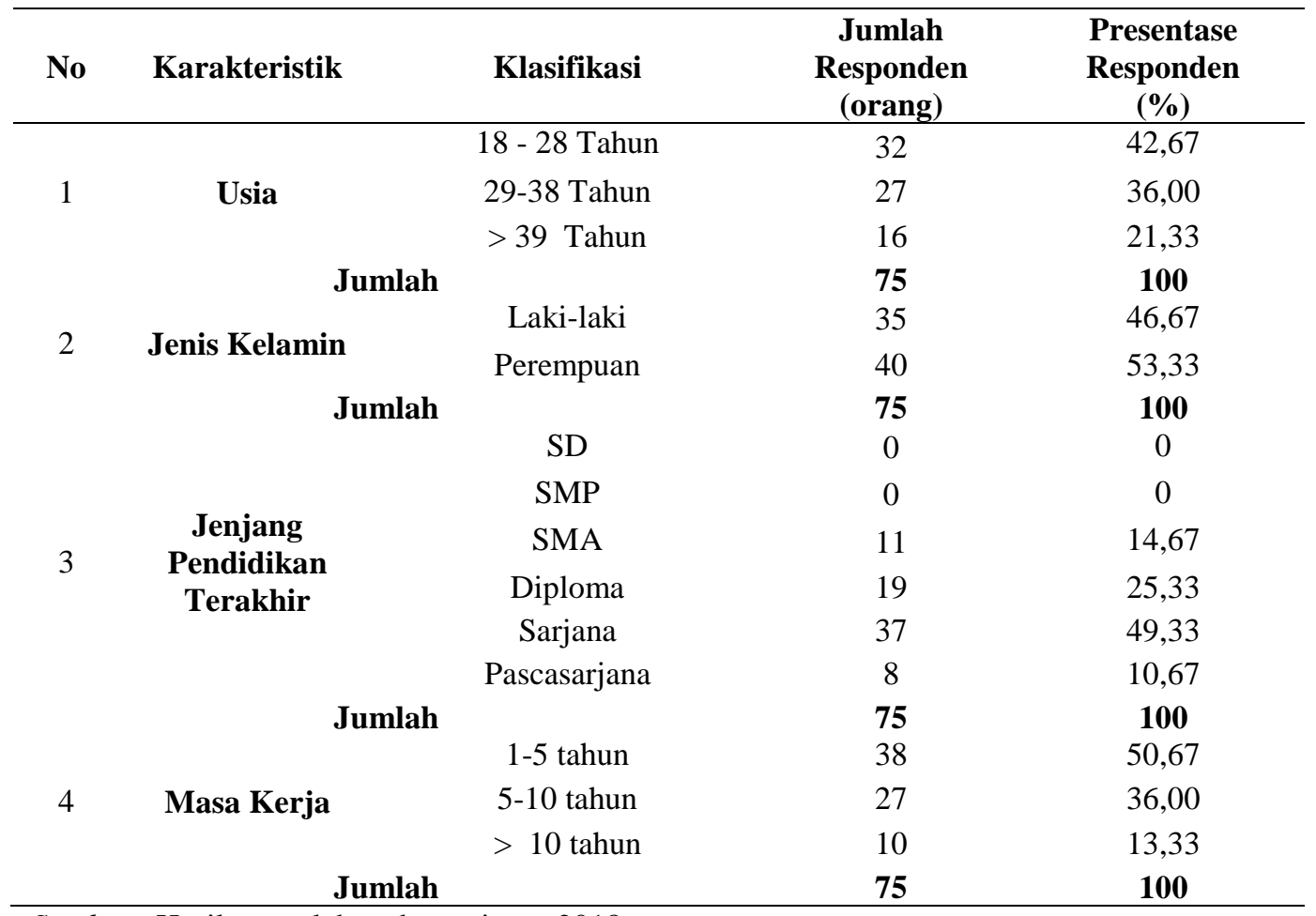

Sumber : Hasil pengolahan data primer, 2018

Tabel 2 menunjukkan responden dalam penelitian ini yaitu pegawai di Dinas Tenaga Kerja dan Sumber Daya Mineral Provinsi Bali dominan berjenis kelamin perempuan dengan persentase 53,33 persen. Artinya lebih banyak pegawai perempuan dibandingkan laki-laki yang bekerja di Dinas Tenaga Kerja dan Sumber Daya Mineral Provinsi Bali. Dilihat dari segi usia, responden sebagian besar berusia 18-28 tahun dengan jumlah sebanyak 32 orang dengan persentase sebesar 42,67 persen. Kelompok usia 18-28 tahun merupakan kelompok usia produktif. Faktor usia seorang pegawai yang produktif dapat menunjang kegiatan organisasi dalam menghasilkan organisasi yang berkualitas, 
karena dengan umur produktif yang dimiliki akan berkorelasi di dalam pencapaian tujuan organisasi tersebut.

Tabel 2 menunjukkan mayoritas pegawai di Dinas Tenaga Kerja dan Sumber Daya Mineral Provinsi Bali adalah kelompok responden dengan tingkat pendidikan Sarjana dengan jumlah sebanyak 37 orang atau 49,33 persen, kemudian responden dengan tingkat pendidikan Diploma sebanyak 19 orang atau 25,33 persen, responden dengan tingkat pendidikan SMA sebanyak 11 orang atau 14,67 persen dan Pascasarjana sebanyak 8 orang atau 10,67 persen. Informasi ini memberikan gambaran bahwa pegawai di Dinas Tenaga Kerja dan Sumber Daya Mineral Provinsi Bali paling dominan adalah lulusan Sarjana yang dianggap sudah mampu serta memadai untuk menjadi pegawai pemerintahan yang memiliki kompetensi untuk mencapai tujuan organisasi.

Pengelompokkan responden berdasarkan masa kerja menunjukkan bahwa responden yang bekerja di Dinas Tenaga Kerja dan Sumber Daya Mineral Provinsi Bali dengan masa kerja selama 1 sampai 5 tahun adalah sebanyak 38 orang atau 50,67 persen, kemudian responden yang bekerja selama 5 sampai 10 tahun sebanyak 27 orang atau 26,47 persen, sedangkan yang bekerja lebih dari 10 tahun sebanyak 10 orang atau 13,33 persen. Artinya sebagian besar pegawai di Dinas Tenaga Kerja dan Sumber Daya Mineral Provinsi Bali memiliki masa kerja 1 sampai 5 tahun yang menunjukkan bahwa terdapat banyak lulusan sarjana muda yang baru bekerja di Dinas Tenaga Kerja dan Sumber Daya Mineral Provinsi Bali. Hal ini diharapkan mampu mencapai tujuan organisasi karena lulusan sarjana 
muda memiliki produktivitas dan kinerja yang kompeten untuk menjadi pegawai pemerintahan yang baik.

Hasil penilaian responden mengenai variabel iklim organisasi $\left(\mathrm{X}_{1}\right)$ dapat dilihat pada Tabel 3 Hasil analisis deksriptif sebagaimana disajikan pada tabel 3 menunjukkan bahwa variabel iklim organisasi secara keseluruhan memperoleh nilai rata-rata sebesar 3,92, yang berarti bahwa sebagian besar pegawai merasa jika iklim organisasi pada Dinas Tenaga Kerja dan Energi Sumber Daya Mineral Provinsi Bali sudah terbentuk dengan baik. Dari 7 indikator yang digunakan untuk mengukur iklim organisasi, maka terdapat 3 indikator yang nilainya berada di atas nilai rata-rata $(3,92)$ variabel iklim organisasi yaitu indikator kepemimpinan, indikator kepercayaan dan indikator pembuatan keputusan bersama atau dukungan.

Tabel 3.

Deskripsi Penilaian Responden Terhadap Variabel Iklim organisasi

\begin{tabular}{|c|c|c|c|c|c|c|c|}
\hline \multirow[t]{2}{*}{ Indikator } & \multicolumn{5}{|c|}{$\begin{array}{c}\text { Frekuensi Jawaban } \\
\text { Responden }\end{array}$} & \multirow{2}{*}{$\begin{array}{l}\text { Rata - } \\
\text { Rata }\end{array}$} & \multirow[t]{2}{*}{ Keterangan } \\
\hline & 1 & 2 & 3 & 4 & 5 & & \\
\hline Kepemimpinan $\left(\mathrm{X}_{1.1}\right)$ & 0 & 5 & 15 & 32 & 23 & 3,97 & Baik \\
\hline Kepercayaan $\left(\mathrm{X}_{1.2}\right)$ & 0 & 3 & 17 & 34 & 21 & 3,97 & Baik \\
\hline $\begin{array}{l}\text { Pembuatan keputusan bersama atau } \\
\text { dukungan }\left(\mathrm{X}_{1.3}\right)\end{array}$ & 1 & 4 & 19 & 25 & 26 & 3,95 & Baik \\
\hline Kejujuran $\left(\mathrm{X}_{1.4}\right)$ & 0 & 4 & 21 & 29 & 21 & 3,89 & Baik \\
\hline Resiko pekerjaan $\left(\mathrm{X}_{1.5}\right)$ & 2 & 2 & 18 & 38 & 15 & 3,83 & Baik \\
\hline $\begin{array}{l}\text { Fleksibel atau atonomi } \\
\text { keotonomian }\left(\mathrm{X}_{1.6}\right)\end{array}$ & 1 & 4 & 20 & 27 & 23 & 3,89 & Baik \\
\hline Komunikasi $\left(\mathrm{X}_{1.7}\right)$ & 1 & 6 & 9 & 42 & 17 & 3,91 & Baik \\
\hline \multicolumn{6}{|c|}{ Rata-rata Skor Variabel Iklim Organisasi } & 3,92 & Baik \\
\hline
\end{tabular}

Sumber: Data primer diolah, 2018

Dari ketiga indikator tersebut, yang memiliki nilai paling tinggi adalah indikator kepemimpinan, dan kepercayaan. Hal tersebut disebabkan karena pimpinan atau kepala Dinas Tenaga Kerja dan Energi Sumber Daya Mineral 
Provinsi Bali sudah mampu mengkoordinasikan dan menggerakan pegawai untuk mencapai tujuan organisasinya dengan baik. Selain itu, sebagian besar pegawai memiliki sikap saling percaya, baik antar pegawai maupun dengan pimpinan dan pegawai juga mampu mempertahankan hubungan yang penuh kepercayaan tersebut, sehingga iklim organisasi pada Dinas Tenaga Kerja dan Energi Sumber Daya Mineral Provinsi Bali mampu terbentuk dengan baik.

Skor rata-rata terendah pada variabel iklim organisasi terdapat pada indikator resiko pekerjaan dengan nilai rata-rata sebesar 3,83. Indikator resiko pekerjaan sudah memperoleh penilaian yang baik dari pegawai berdasarkan hasil kuisioner, namun masih lebih rendah dari nilai rata-rata variabel iklim organisasi. Hal tersebut menunjukkan bahwa masih ada beberapa orang pegawai yang tidak menyadari akibat jika tidak menyelesaikan pekerjaan yang telah ditentukan. Oleh karena itu, dalam upaya meningkatkan iklim organisasi menjadi lebih baik, maka Dinas Tenaga Kerja dan Energi Sumber Daya Mineral Provinsi Bali sebaiknya membuat sosialisasi dan pemahaman mengenai sanksi tegas yang akan diberikan pada pegawai bilamana tidak menyelesaikan pekerjaan dengan baik dan tepat waktu. Dengan memberi sosialisasi dan pemahaman kepada seluruh pegawai, diharapkan dapat meningkatkan iklim organisasi dan kinerja pegawai menjadi lebih baik.

Hasil penilaian responden mengenai variabel disiplin kerja $\left(\mathrm{X}_{2}\right)$ dapat dilihat pada Tabel 4 Hasil analisis deksriptif sebagaimana disajikan pada tabel 4 menunjukkan bahwa variabel disiplin kerja secara keseluruhan memperoleh nilai rata-rata sebesar 3,87, yang berarti bahwa sebagian besar pegawai Dinas Tenaga 
Kerja dan Energi Sumber Daya Mineral Provinsi Bali sudah memiliki sikap yang disiplin. Dari 4 indikator yang digunakan untuk mengukur disiplin kerja, maka terdapat 3 indikator yang nilainya berada di atas nilai rata-rata $(3,87)$ variabel disiplin kerja yaitu indikator ketepatan waktu, indikator menggunakan peralatan kantor dengan baik dan indikator ketaatan terhadap aturan kantor. Dari ketiga indikator tersebut, yang memiliki nilai paling tinggi adalah indikator menggunakan peralatan kantor dengan baik. Hal tersebut disebabkan karena sebagian besar responden selalu hati-hati dalam menggunakan peralatan kantor, agar tidak mudah rusak dan dapat digunakan dalam jangka waktu panjang. Selain itu, sebagian besar pegawai selalu datang tepat waktu untuk bekerja dan selalu membuat izin apabila tidak masuk kantor, sehingga disiplin kerja pegawai pada Dinas Tenaga Kerja dan Energi Sumber Daya Mineral Provinsi Bali mampu terbentuk dengan baik.

Skor rata-rata terendah pada variabel disiplin kerja terdapat pada indikator tanggung jawab yang tinggi dengan nilai rata-rata sebesar 3,60. Indikator tanggung jawab yang tinggi sudah memperoleh penilaian yang baik dari pegawai berdasarkan hasil kuisioner, namun masih lebih rendah dari nilai rata-rata variabel disiplin kerja. Hal tersebut menunjukkan bahwa masih ada beberapa orang pegawai yang tidak mampu menyelesaikan tugas dengan penuh tanggung jawab sesuai dengan prosedur yang telah ditentukan. Oleh karena itu, dalam upaya meningkatkan disiplin kerja pegawai, maka Dinas Tenaga Kerja dan Energi Sumber Daya Mineral Provinsi Bali sebaiknya membuat program pelatihan dan 
pengembangan secara rutin bagi seluruh pegawai agar seluruh pegawai mampu menyelesaikan pekerjaan dengan baik dan tepat waktu.

Tabel 4.

Deskripsi Penilaian Responden Terhadap Variabel Disiplin kerja

\begin{tabular}{|c|c|c|c|c|c|c|c|}
\hline \multirow[t]{2}{*}{ Indikator } & \multicolumn{5}{|c|}{$\begin{array}{c}\text { Frekuensi Jawaban } \\
\text { Responden } \\
\end{array}$} & \multirow{2}{*}{$\begin{array}{l}\text { Rata - } \\
\text { Rata }\end{array}$} & \multirow[t]{2}{*}{ Keterangan } \\
\hline & 1 & 2 & 3 & 4 & 5 & & \\
\hline Ketepatan waktu $\left(\mathrm{X}_{2.2}\right)$ & 1 & 3 & 10 & 44 & 17 & 3,97 & Tinggi \\
\hline $\begin{array}{l}\text { Menggunakan peralatan kantor } \\
\text { dengan baik }\left(\mathrm{X}_{2.2}\right)\end{array}$ & 2 & 2 & 15 & 32 & 24 & 3,99 & Tinggi \\
\hline Tanggung jawab yang tinggi $\left(\mathrm{X}_{2.3}\right)$ & 1 & 5 & 27 & 32 & 10 & 3,60 & Tinggi \\
\hline $\begin{array}{l}\text { Ketaatan terhadap aturan kantor } \\
\left(\mathrm{X}_{2.4}\right)\end{array}$ & 0 & 4 & 16 & 36 & 19 & 3,93 & Tinggi \\
\hline \multicolumn{6}{|c|}{ Rata-rata Skor Variabel Disiplin Kerja } & 3,87 & Tinggi \\
\hline
\end{tabular}

Sumber: Data primer diolah, 2018

Hasil penilaian responden mengenai variabel kepemimpinan $\left(\mathrm{X}_{3}\right)$ dapat dilihat pada Tabel 5 Hasil analisis deksriptif sebagaimana disajikan pada Tabel 5 menunjukkan bahwa variabel kepemimpinan secara keseluruhan memperoleh nilai rata-rata sebesar 4,02, yang berarti bahwa sebagian besar pegawai menilai kepemimpinan pada Dinas Tenaga Kerja dan Energi Sumber Daya Mineral Provinsi Bali sudah berjalan dengan baik. Dari 4 indikator yang digunakan untuk mengukur kepemimpinan, maka terdapat 2 indikator yang nilainya berada di atas nilai rata-rata $(4,02)$ variabel kepemimpinan yaitu indikator inspirational motivation dan indikator idealized influence. Dari dua indikator tersebut, yang memiliki nilai paling tinggi adalah indikator inspirational motivation. Hal tersebut disebabkan karena pimpinan atau kepala Dinas Tenaga Kerja dan Energi Sumber Daya Mineral Provinsi Bali selama ini selalu memiliki ide yang dapat di terima dengan baik oleh seluruh pegawai. Selain itu, pimpinan juga mampu membangkitkan antusiasme pegawai dalam melakukan pekerjaan, sehingga 
kepemimpinan pada Dinas Tenaga Kerja dan Energi Sumber Daya Mineral Provinsi Bali mampu terlaksana dengan baik.

Skor rata-rata terendah pada variabel kepemimpinan terdapat pada indikator individual consideration dengan nilai rata-rata sebesar 3,73. Indikator individual consideration sudah memperoleh penilaian yang baik dari pegawai berdasarkan hasil kuisioner, namun masih lebih rendah dari nilai rata-rata variabel kepemimpinan. Hal tersebut menunjukkan bahwa masih ada beberapa orang pegawai yang tidak diperhatikan kebutuhannya dalam melaksanakan pekerjaan. Oleh karena itu, dalam upaya meningkatkan kepemimpinan menjadi lebih baik, maka kepala Dinas Tenaga Kerja dan Energi Sumber Daya Mineral Provinsi Bali sebaiknya meningkatkan perhatiannya kepada seluruh pegawai secara adil terhadap kebutuhan pegawai dalam melaksanakan pekerjaan. Dengan memberikan perhatian dan pengertian pada kebutuhan seluruh pegawai, akan membuat pegawai merasa diperhatikan oleh pimpinan, sehingga diharapkan dapat meningkatkan kinerja pegawai menjadi lebih baik.

Hasil penilaian responden mengenai variabel kepemimpinan $\left(\mathrm{X}_{3}\right)$ dapat dilihat pada Tabel 6 Hasil analisis deksriptif sebagaimana disajikan pada Tabel 6 menunjukkan bahwa variabel kepuasan kerja secara keseluruhan memperoleh nilai rata-rata sebesar 3,94 , yang berarti bahwa sebagian besar pegawai pada Dinas Tenaga Kerja dan Energi Sumber Daya Mineral Provinsi Bali memiliki kepuasan kerja yang tinggi. Dari 5 indikator yang digunakan untuk mengukur kepuasan kerja, maka terdapat 2 indikator yang nilainya berada di atas nilai ratarata $(3,94)$ variabel kepuasan kerja yaitu indikator pekerjaan (job) dan indikator 
rekan kerja (co-workers). Dari dua indikator tersebut, yang memiliki nilai paling tinggi adalah indikator pekerjaan (job). Hal tersebut disebabkan karena pimpinan atau kepala Dinas Tenaga Kerja dan Energi Sumber Daya Mineral Provinsi Bali sudah memberikan kesempatan kepada pegawai untuk menerima tanggung jawab atas pekerjaan. Selain itu, sebagian besar pegawai senang memiliki rekan kerja yang saling mendukung dalam menyelesaikan pekerjaan, sehingga kepuasan kerja pegawai mampu terbentuk dengan baik.

Skor rata-rata terendah pada variabel kepuasan kerja terdapat pada indikator Atasan (Supervisor) dengan nilai rata-rata sebesar 3,81. Indikator Atasan (Supervisor) sudah memperoleh penilaian yang baik dari pegawai, namun masih lebih rendah dari nilai rata-rata variabel kepuasan kerja. Hal tersebut menunjukkan bahwa masih ada beberapa orang pegawai yang merasa jika pimpinan tidak bersedia memberikan bantuan teknis pada pegawai yang mengalami kesulitan.

Tabel 5.

Deskripsi Penilaian Responden Terhadap Variabel Kepuasan kerja

\begin{tabular}{|c|c|c|c|c|c|c|c|}
\hline \multirow[t]{2}{*}{ Indikator } & \multicolumn{5}{|c|}{$\begin{array}{c}\text { Frekuensi Jawaban } \\
\text { Responden }\end{array}$} & \multirow{2}{*}{$\begin{array}{l}\text { Rata - } \\
\text { Rata }\end{array}$} & \multirow[t]{2}{*}{ Keterangan } \\
\hline & 1 & 2 & 3 & 4 & 5 & & \\
\hline Pembayaran $\left(\right.$ Pay) $\left(\mathrm{Y}_{1}\right)$ & 0 & 5 & 19 & 31 & 20 & 3,88 & Tinggi \\
\hline Pekerjaan $(\mathrm{Job})\left(\mathrm{Y}_{2}\right)$ & 1 & 2 & 13 & 31 & 28 & 4,11 & Tinggi \\
\hline $\begin{array}{l}\text { Kesempatan promosi (Promotion } \\
\text { opportunities) }\left(\mathrm{Y}_{3}\right)\end{array}$ & 1 & 3 & 19 & 31 & 21 & 3,91 & Tinggi \\
\hline Atasan (Supervisor) $\left(\mathrm{Y}_{4}\right)$ & 1 & 6 & 18 & 31 & 19 & 3,81 & Tinggi \\
\hline Rekan kerja (Co-workers) $\left(\mathrm{Y}_{5}\right)$ & 0 & 2 & 15 & 41 & 17 & 3,97 & Tinggi \\
\hline \multicolumn{6}{|c|}{ Rata-rata Skor Variabel Kepuasan Kerja } & 3,94 & Tinggi \\
\hline
\end{tabular}

Sumber: Data primer diolah, 2018

Oleh karena itu, dalam upaya meningkatkan kepuasan kerja pegawai menjadi lebih baik, maka kepala Dinas Tenaga Kerja dan Energi Sumber Daya 
Mineral Provinsi Bali sebaiknya bersedia memberikan bantuan teknis pada pegawai yang mengalami kesulitan sehingga nantinya dapat meningkatkan kepuasan kerja pegawai dan pada akhirnya kinerja pegawai menjadi lebih baik. Hasil pengujian semua asumsi klasik dalam penelitian ini sudah terpenuhi, sehingga hasil analisis regresi layak untuk dibahas lebih lanjut. Perhitungan koefisien regresi linier berganda dilakukan dengan analisis regresi melalui software SPSS 18.0 for Windows, diperoleh hasil yang ditunjukan pada Tabel 6.

Tabel 6.

Rangkuman Hasil Analisis Regresi Linear Berganda

\begin{tabular}{|c|c|c|c|c|c|}
\hline \multirow{2}{*}{ Variabel } & & \multicolumn{2}{|c|}{ Koefisien Regresi } & \multirow{2}{*}{$\mathrm{t}$} & \multirow{2}{*}{ Sig } \\
\hline & & B & Std. error & & \\
\hline (Constant) & & 2,610 & 1,860 & 1,403 & 0,165 \\
\hline Iklim organisasi & & 0,456 & 0,066 & 4,924 & 0,000 \\
\hline Disiplin kerja & & 0,240 & 0,109 & 2,511 & 0,014 \\
\hline Kepemimpinan & & 0,233 & 0,093 & 2,589 & 0,012 \\
\hline Dependen variabel & : & kepuasan kerja & & & \\
\hline F Statistik & : & 28,753 & & & \\
\hline Sig F & : & 0.000 & & & \\
\hline $\mathrm{R}^{2}$ & : & 0,549 & & & \\
\hline
\end{tabular}

Berdasarkan hasil analisis regresi linier berganda seperti yang disajikan pada Tabel 6, maka dapat dibuat persamaan regresi sebagai berikut:

$$
Y=2,610+0,456 X_{1}+0,240 X_{2}+0,233 X_{3}
$$

Nilai koefisien regresi masing-masing variabel bebas bernilai positif dengan nilai signifikansi uji t kurang dari 0,05. Hal ini menunjukkan bahwa semua variabel bebas memiliki pengaruh positif yang signifikan terhadap variabel terikat. Besarnya pengaruh variabel bebas terhadap variabel terikat yang ditunjukkan oleh nilai determinasi total (R Square) sebesar 0,549 mempunyai arti bahwa sebesar 54,9\% variasi kepuasan kerja pegawai Dinas Tenaga Kerja dan 
Energi Sumber Daya Mineral Provinsi Bali dipengaruhi oleh variasi iklim organisasi, disiplin kerja, dan kepemimpinan, sedangkan sisanya sebesar $45,1 \%$ djelaskan oleh faktor lain yang tidak dimasukkan ke dalam model.

Hasil uji F (Ftest) menunjukkan bahwa nilai signifikansi P value 0,000 yang lebih kecil dari $\alpha=0,05$, ini berarti model yang digunakan pada penelitian ini adalah layak. Hasil ini memberikan makna bahwa seluruh variabel independen mampu memprediksi atau menjelaskan fenomena kepuasan kerja pegawai Dinas Tenaga Kerja dan Energi Sumber Daya Mineral Provinsi Bali. Hal ini berarti model dapat digunakan untuk analisa lebih lanjut atau dengan kata lain model dapat digunakan untuk memproyeksikan karena hasil goodness of fitnya baik dengan nilai signifikansi P value 0,000 .

\section{Pengaruh Iklim Organisasi Terhadap Kepuasan Kerja Pegawai}

Berdasarkan hasil analisis pengaruh Iklim organisasi terhadap Kepuasan kerja diperoleh nilai Signifikasi sebesar 0,000 dengan nilai koefisien beta 0,456. Nilai Signifikansi $0,000<0,05$ mengindikasikan bahwa $\mathrm{H}_{0}$ ditolak dan $\mathrm{H}_{1}$ diterima. Hasil ini mempunyai arti bahwa Iklim organisasi berpengaruh positif dan signifikan terhadap Kepuasan kerja pegawai Dinas Tenaga Kerja dan Energi Sumber Daya Mineral Provinsi Bali. Semakin baik iklim organisasi Dinas Tenaga Kerja dan Energi Sumber Daya Mineral Provinsi Bali maka akan semakin tinggi pula kepuasan kerja yang dirasakan pegawai. Begitu pula sebaliknya, semakin buruk iklim organisasi pada Dinas Tenaga Kerja dan Energi Sumber Daya Mineral Provinsi Bali, maka akan semakin mengurangi kepuasan kerja yang dirasakan pegawai. 
Iklim organisasi yang kondusif sangat penting untuk mencapai kesuksesan organisasi. Dengan iklim yang kondusif akan menimbulkan kepuasan kerja dan komitmen yang tinggi pada setiap individu yang bekerja didalam organisasi tersebut (Susanty, 2012). Terdapat hubungan yang positif antara iklim organisasi dengan kepuasan kerja, yang diartikan dengan semakin favorable (menyenangkan) iklim kerja suatu lembaga, maka semakin tinggi pula kepuasan kerja yang dirasakan pegawainya dan sebaliknya. Semakin unfavorable (tidak menyenangkan) iklim kerja suatu lembaga, maka semakin rendah pula kepuasan kerja yang dirasakan pegawainya (Putra dkk., 2014).

Penelitian ini mendukung beberapa hasil penelitian sebelumnya dan konsisten dengan hasil penelitian yang dilakukan oleh Akbar dkk. (2017), Koti Akula dan Talluri (2013), Rachman (2013), Rahmawati dan Supartha (2015), Robirodia dan Prihatin (2016), serta Sutaji (2013) yang memperoleh hasil bahwa iklim organisasi berpengaruh positif dan signifikan terhadap kepuasan kerja pegawai. Apabila atasan dan rekan kerja saling mendukung dalam bekerja dan pembagian tugas diberikan sesuai dengan peran masing-masing pagawai sehingga pegawai merasa iklim organisasinya baik, maka pada akhirnya akan berdampak pada meningkatnya kepuasan kerja pegawai tersebut.

\section{Pengaruh Disiplin kerja terhadap Kepuasan kerja}

Berdasarkan hasil analisis pengaruh disiplin kerja terhadap kepuasan kerja diperoleh nilai signifikansi sebesar 0,014 dengan nilai koefisien beta 0,240. Nilai Signifikansi 0,014 $<0,05$ mengindikasikan bahwa $\mathrm{H}_{0}$ ditolak dan $\mathrm{H}_{2}$ diterima. Hasil ini mempunyai arti bahwa Disiplin kerja berpengaruh positif dan signifikan 
terhadap Kepuasan kerja pegawai Dinas Tenaga Kerja dan Energi Sumber Daya Mineral Provinsi Bali. Semakin tinggi disiplin kerja seorang pegawai Dinas Tenaga Kerja dan Energi Sumber Daya Mineral Provinsi Bali maka kepuasan kerja pegawai tersebut juga akan semakin bertambah. Begitu pula sebaliknya, semakin rendah disiplin kerja seorang pegawai Dinas Tenaga Kerja dan Energi Sumber Daya Mineral Provinsi Bali, maka semakin rendah tingkat kepuasan kerja pegawai tersebut.

Disiplin kerja merupakan suatu faktor yang penting dalam meningkatkan kepuasan kerja karena disiplin merupakan sesuatu yang penting untuk organisasi dalam menciptakan efektifitas terhadap pekerjaan. Seseorang yang mempunyai disiplin kerja yang tinggi akan bekerja dengan baik tanpa adanya pengawasan. Kedisiplinan yang terbentuk dalam diri pegawai tanpa adanya paksaan menimbulkan hal yang baik dengan mentaati segala peraturan yang berlaku dalam organisasi dan akan mencapai kematangan psikologis sehingga menimbulkan rasa puas dalam diri seseorang (Yunus dan Bachri, 2013). Penelitian ini mendukung beberapa hasil penelitian sebelumnya dan konsisten dengan hasil penelitian Riyanto (2016) yang memperoleh hasil bahwa disiplin kerja berpengaruh terhadap kepuasan kerja. Bila pegawai memiliki disiplin kerja yang tinggi, diharapkan akan mampu menyelesaikan tugas dengan cepat dan tepat sehingga timbul kepuasan kerja. Penelitian ini juga di dukung oleh hasil penelitian Mardiono dan Supriyatin (2014), serta Huda (2017) yang memperoleh hasil bahwa semakin tinggi disiplin kerja maka semakin tinggi kepuasan kerja 


\section{Pengaruh Kepemimpinan terhadap Kepuasan kerja}

Berdasarkan hasil analisis pengaruh Kepemimpinan terhadap Kepuasan kerja diperoleh nilai signifikansi sebesar 0,012 dengan nilai koefisien beta 0,233. Nilai signifikansi $0,012<0,05$ mengindikasikan bahwa $\mathrm{H}_{0}$ ditolak dan $\mathrm{H}_{3}$ diterima. Hasil ini mempunyai arti bahwa Kepemimpinan berpengaruh positif dan signifikan terhadap Kepuasan kerja pegawai Dinas Tenaga Kerja dan Energi Sumber Daya Mineral Provinsi Bali. Semakin baik tingkat kepemimpinan maka akan berpengaruh pada semakin meningkatnya kepuasan kerja pegawai Dinas Tenaga Kerja dan Energi Sumber Daya Mineral Provinsi Bali. Begitu pula sebaliknya, semakin buruk tingkat kepemimpinan pada Dinas Tenaga Kerja dan Energi Sumber Daya Mineral Provinsi Bali maka akan berpengaruh pada semakin berkurangnya kepuasan kerja pegawai.

Pemberian kepuasan kerja tidak lepas dari peran seorang pemimpin dalam mengatur kebijakan yang terstruktur dalam organisasi. Kepemimpinan yang efektif sebagai suatu bentuk pencapaian aturan kondisi kerja yang optimal untuk pencapaian tujuan perseorangan maupun tujuan organisasi sehingga dapat menimbulkan kepuasan kerja yang besar kepada setiap pegawai. Seorang pimpinan mempunyai tanggung jawab yang besar terhadap kepuasan bawahannya seperti pemberian gaji, menciptakan kondisi kerja yang baik sehingga dapat menciptakan ketenangan kerja yang menimbulkan kepuasan dalam bekerja (Yunus dan Bachri, 2013).

Penelitian ini mendukung beberapa hasil penelitian sebelumnya dan konsisten dengan hasil penelitian yang dilakukan oleh Wusyang dan Tawas, 
(2016) yang menunjukkan bahwa perilaku kepemimpianan berpengaruh signifikan terhadap kepuasan kerja pegawai. Hasil penelitian ini juga di dukung oleh Sapila, (2013), Simanungkalit (2013) dan Priyono (2012) yang memperoleh hasil bahwa ada pengaruh yang positif dan signifikan antara gaya kepemimpinan terhadap kepuasan kerja pegawai.

Berdasarkan hasil penelitian yang diperoleh terdapat beberapa implikasi strategis yaitu Pertama, hasil survei menunjukkan bahwa indikator kepemimpinan, dan kepercayaan menjadi faktor penting dalam meningkatkan iklim organisasi yang baik. Dengan adanya sikap kepala Dinas Tenaga Kerja dan ESDM Provinsi Bali yang mampu mengkoordinasikan dan menggerakan pegawai untuk mencapai tujuan organisasinya dengan baik, serta adanya sikap saling percaya, baik antar pegawai maupun antara pimpinan dan pegawai yang mampu mempertahankan hubungan dengan penuh kepercayaan maka iklim organisasi pada Dinas Tenaga Kerja dan ESDM Provinsi Bali mampu terbentuk dengan baik.

Kedua, hasil survei menunjukkan bahwa tinggi rendahnya disiplin kerja pegawai disebabkan oleh ketepatan waktu, cara menggunakan peralatan kantor dengan baik dan ketaatan terhadap aturan kantor. Indikator yang menjadi faktor penting dalam meningkatkan disiplin kerja pegawai Dinas Tenaga Kerja dan ESDM Provinsi Bali adalah cara menggunakan peralatan kantor dengan baik. Hal tersebut disebabkan karena sebagian besar responden selalu hati-hati dalam menggunakan peralatan kantor, agar tidak mudah rusak dan dapat digunakan dalam jangka waktu panjang. 
Ketiga, hasil survei menunjukkan bahwa kepala Dinas Tenaga Kerja dan ESDM Provinsi Bali lebih cenderung menerapkan gaya kepemimpinan inspirational motivation, sehingga indikator ini menjadi faktor penting yang mampu meningkatkan persepsi pegawai terhadap kepemimpinan yang baik. Dengan adanya sikap kepala Dinas Tenaga Kerja dan ESDM Provinsi Bali yang selama ini selalu memiliki ide yang dapat di terima dengan baik oleh seluruh pegawai, maka akan mendorong meningkatnya gaya kepemimpinan di Dinas Tenaga Kerja dan ESDM Provinsi Bali

Keempat, hasil survei menunjukkan bahwa tinggi rendahnya kepuasan kerja pegawai disebabkan oleh indikator pekerjaan (job). Hal tersebut disebabkan karena pimpinan atau kepala Dinas Tenaga Kerja dan ESDM Provinsi Bali sudah memberikan kesempatan kepada pegawai untuk menerima tanggung jawab atas pekerjaan. Selain itu, sebagian besar pegawai senang memiliki rekan kerja yang saling mendukung dalam menyelesaikan pekerjaan, sehingga kepuasan kerja pegawai pada Dinas Tenaga Kerja ESDM Provinsi Bali terbentuk dengan baik.

\section{SIMPULAN DAN SARAN}

Simpulan yang dapat diberikan berdasarkan pada pembahasan dan hasil analisis dalam penelitian ini yaitu yang pertama, iklim organisasi berpengaruh positif dan signifikan terhadap Kepuasan kerja pegawai Dinas Tenaga Kerja dan ESDM Provinsi Bali. Kedua, disiplin kerja berpengaruh positif dan signifikan terhadap kepuasan kerja pegawai Dinas Tenaga Kerja dan ESDM Provinsi Bali. Ketiga, kepemimpinan berpengaruh positif dan signifikan terhadap kepuasan kerja pegawai Dinas Tenaga Kerja dan ESDM Provinsi Bali. 
Saran yang dapat diberikan berdasarkan hasil penelitian yaitu pertama, dalam upaya meningkatkan iklim organisasi menjadi lebih baik, maka Dinas Tenaga Kerja dan ESDM Provinsi Bali sebaiknya membuat sosialisasi dan pemahaman mengenai sanksi tegas yang akan diberikan pada pegawai bilamana tidak menyelesaikan pekerjaan dengan baik dan tepat waktu. Dengan memberi sosialisasi dan pemahaman kepada seluruh pegawai, diharapkan dapat meningkatkan iklim organisasi dan kinerja pegawai menjadi lebih baik. Kedua, dalam upaya meningkatkan disiplin kerja pegawai, maka Dinas Tenaga Kerja dan ESDM Provinsi Bali sebaiknya membuat program pelatihan dan pengembangan secara rutin bagi seluruh pegawai agar seluruh pegawai mampu menyelesaikan pekerjaan dengan baik dan tepat waktu.

Ketiga, dalam upaya meningkatkan kepemimpinan menjadi lebih baik, maka kepala Dinas Tenaga Kerja dan ESDM Provinsi Bali sebaiknya meningkatkan perhatiannya kepada seluruh pegawai secara adil terhadap kebutuhan pegawai dalam melaksanakan pekerjaan. Dengan memberikan perhatian dan pengertian pada kebutuhan seluruh pegawai, akan membuat pegawai merasa diperhatikan oleh pimpinan, sehingga diharapkan dapat meningkatkan kinerja pegawai menjadi lebih baik. Keempat, dalam upaya meningkatkan kepuasan kerja pegawai menjadi lebih baik, maka kepala Dinas Tenaga Kerja dan ESDM Provinsi Bali sebaiknya bersedia memberikan bantuan teknis pada pegawai yang mengalami kesulitan sehingga nantinya dapat meningkatkan kepuasan kerja pegawai dan pada akhirnya kinerja pegawai menjadi lebih baik. 
Penelitian selanjutnya juga diharapkan dapat menambah jumlah sampel penelitian serta memperluas wilayah sampel peneliti, dan dapat melakukan penelitian pada beberapa lembaga pemerintah Provinsi Bali sehingga nanti hasilnya dapat digeneralisasikan untuk lingkup yang lebih luas

\section{REFERENSI}

Akbar S, Edy., Mattalatta, dan Gunawan. 2017. Pengaruh Motivasi, Kompensasi Dan Iklim Organisasi Terhadap Kepuasan Kerja Pegawai Dinas Pemuda Dan Olahraga Kabupaten Sinjai. Jurnal Mirai Management Volume 2 No. 2 April, Hal: 257-269

Azzem, Hazem Kamal EI Din and Shaima Salah Sayed. 2010. Influence of Empowering Employes on Job Satisfaction in Youth Care Administrations at Faculties of Assiut University A Comperative Study. World Journal of Sport Sciensces, 3(S), pp:1151-1159.

Chaidar, Diar Fachmi R. 2016. Pengaruh Kompensasi, Iklim Kerja, dan Kepemimpinan Transformasional terhadap Kepuasan Kerja serta Implikasinya pada Loyalitas Kerja. Jurnal Kontingensi. Vil. 4, No. 1, Hal: 43-56.

Huda, Ahmad Nurul. 2017. Pengaruh Motivasi Kerja Dan Disiplin Kerja Terhadap Kepuasan Kerja Pegawai Koperasi Simpan Pinjam Unit Desa Karya Mukti Di Kecamatan Pelepat Ilir Kabupaten Bungo. Jurnal Jurusan Pendidikan Ilmu Pengetahuan Sosial Fakultas Keguruan Dan Ilmu Pendidikan Universitas Jambi. Hal: 1-10

Kharim, Faisal. and Omar Rehman. 2012. Impact of Job Satisfaction, Perceived Organizational Justice and Employee Empowerment on Organizational Commitment in Semi-Government Organizations of Pakistan. Journal of Business Studies Quarterly 2012, Vol. 3, No. 4, pp. 92-104.

Koti Akula, Rathna Lakshmi. \& Sreenivas Talluri. 2013. Impact of Organisational Climate on Job Satisfaction of Doctors in Hospitals of Andhra Pradesh, India. International Journal of Social Science \& Management, 3 (3), pp: 76-80.

Lineker, Arru Gideon. Tetra Hidayati, dan Siti Maria. 2016. Pengaruh Iklim Organisasi Dan Kepuasan Kerja Serta Komitmen Organisasional Terhadap Kinerja Pegawai. Jurnal Ekonomi Keuangan, dan Manajemen, Volume 12, No. 2, Hal: 250-269 
Mardiono, Dian., dan Supriyatin. 2014. Pengaruh Motivasi Dan Disiplin Kerja Terhadap Kepuasan Kerja Pegawai. Jurnal Ilmu \& Riset Manajemen Vol. 3 No. 3, Hal:1-19

Malik, dkk. 2010. Job Satisfaction and Organizational Commitement of University Teachers in Public Sector of Pakistan. International Journal of Bussiness and Management, Vol. 5 No. 6, Juni 201 0, 17-26

McKim, BR, Rutherford, TA, Torres, RM, \& Murphy, TH 2011, 'Organizational Climate of the American Association for Agricultural Education', Journal of Agricultural Education, 52(3), pp. 87-99.

Omar, W. W., and Hussin, F. 2013. Transformational leadership style and job satisfaction relationship. a study of Structural Equation Modeling (SEM). International Journal of Academic Research in Business \& Social Sciences, 3(2), pp.346-365.

Priyono, Fry Medistya Anke. 2012. Pengaruh Gaya Kepemimpinan Terhadap Kepuasan Kerja Dan Komitmen Manajemen Pada Laboratorium Mawar. Journal of Business and Banking. Volume 2, No. 1, Hal: 113 - 122

Putra, Agung Utomo., Endang Siti Atuti, dan Djamhur Hamid. 2014. Pengaruh Iklim Organisasi Terhadap Eustress Dan Kepuasan Kerja Pegawai (Studi Pada Pegawai Perum Jasa Tirta I Malang Jawa Timur). Jurnal Administrasi Bisnis (JAB)|Vol. 14 No. 1, Hal: 1-10

Rachmawati, Sarah. dan Wayan Gede Supartha. 2015. Pengaruh Iklim Organisasi Dan Motivasi Kerja Pada Kepuasan Kerja Pegawai Balai Wilayah Sungai Bali - Penida. E-Jurnal Manajemen Unud, Vol. 4, No. 11, Hal: 3405-3437

Robirodia, Zain Ikhwani Jihadi., dan Eka Prihatin. 2016. Pengaruh Kompensasi dan Iklim Organisasi Sekolah terhadap Kepuasan Kerja Guru non PNS Madrasah Aliyah. Jurnal Administrasi Pendidikan Vol.XXIII No.1, Hal:12-25

Satriyo, Yusuf Firmansyah., dan Idris. 2015. Pengaruh Kepemimpinan, Kompensasi Dan Iklim Organisasi Terhadap Kepuasan Kerja Pegawai Badan Penanggulangan Bencana Daerah (BPBD) Kota Padang. Jurnal Riset Manajemen Bisnis dan Publik. Vol. 3, No. 1, Hal:1-10

Simanungkalit, Yesa Martha Vita. 2013. Pengaruh Gaya Kepemimpinan Terhadap Kepuasan Kerja Pegawai Pada PT. Lion Mentari Airlines. UG Jurnal Vol. 7 No. 06, Hal: 30-33

Styawahyuni, Ari dan Made Yuniari. 2014. Pengaruh Pemberdayaan Pegawai dan Stress Kerja Terhadap Kepuasan Kerja Pegawai. E-Jurnal Manajemen Universitas Udayana. Vol:3. No:6. 
Sun, Li-Yun.,Zhen Zhang, Jin Qi, Zhen Xiong Chen. 2012. Empoerment and Creativity: A Cross-Level Investigtion. The Leadership Quarterly, Vol:23, p: 55-65

Susanty, Etty. 2012. Pengaruh Iklim Organisasi Terhadap Kepuasan Kerja Dan Komitmen Pegawai Pada Universitas Terbuka. Jurnal Organisasi dan Manajemen, Volume 8, Nomor 2, Hal: 121-134

Sutaji, Deddy Sobarna. 2013. Pengaruh Iklim Organisasi Terhadap Kepuasan dan Motivasi Kerja Pegawai Biro Perjalanan Wisata di Kota Bandung. Bisnis dan Manajeme Aset Vol. 1, Hal: 109-128.

Waliningsuci, Trias. Musadieq, dan Djamhur Hamid. 2015. Pengaruh Budaya Organisasi Dan Gaya Kepemimpinan Terhadap Kepuasan Kerja Dan Kinerja Pegawai (Studi Pada Pegawai PT. Entrepreneur Independent Bank (EIB) Indonesia Surabaya). Jurnal Elektronik Universitas Brawijaya. Vol. 2. No. 2. Hal: 1-11

Yunus, Alamsyah., dan Ahmad Alim Bachri. 2013. Pengaruh Disiplin Kerja, Motivasi, Kepemimpinan Terhadap Kepuasan Kerja Pegawai Studi Pada Pt. Bumi Barito Utama Cabang Banjarmasin. Jurnal Wawasan Manajemen, Vol. 1, Nomor 2, Halaman : 167-189. 